\title{
Antimicrobial and Antiadhesion Activity of Biosurfactants from Rhodotorula glutinis Grown on $\boldsymbol{n}$-dodecane
}

\author{
CSUTAK ORTANSA ${ }^{1 *}$, SARBU IONELA ${ }^{1}$, RUSU ELENA $^{2}$, TATIANA VASSU ${ }^{1}$, \\ VIORICA CORBU ${ }^{1}$ \\ ${ }^{1}$ University of Bucharest, Faculty of Biology, Department of Genetics, 1-3 Portocalelor Alley, 60101, Bucharest, Romania \\ ${ }^{2}$ Titu Maiorescu University, Faculty of Medicine, Preclinic Department, 67A Gheorghe Petrascu Str., 031593, \\ Bucharest,Romania
}

\begin{abstract}
The biosurfactants represent a class of biocompounds of growing interest for biomedical applications. The yeast strain Rhodotorula glutinis $C M G B-R G 1$ assimilated normal dodecane $\left(C_{12} H_{26}\right)$ with high rates, producing biosurfactants with constant emulsification index (29\%) after two, respectively, three days. Best antimicrobial activity was recorded for the [50X] concentrated biosurfactant against Candida krusei CMGB-Y8 from vaginal infections. The crude biosurfactant showed high microbial inhibition of biofilms formed by Candida krusei CMGB 94 (35\%), while for C. krusei CMGB-Y8 best results were obtained with [50X] concentrated biosurfactant (47\%) due to the presence of more effective mechanism for biofilm formation and adhesion. The results represent a basis for further studies regarding the characterization of antimicrobial mechanism of action of $R$. glutinis biosurfactants against a large range of human pathogenic microorganisms.
\end{abstract}

Keywords: Rhodotorula glutinis; biosurfactants; antiadhesion; antimicrobial; dodecane

\section{Introduction}

The yeast Candida albicans is the most prevalent cause of candidemia. However, it seems that other Candida species such as $C$. parapsilosis, C. tropicalis, C. glabrata and C. krusei have an important role in causing non-albicans candidemia [1, 2]. Pathogenic Candida species adhere to medical devices and subsequently form biofilms with extremely negative impact on human health [3, 4]. Microbial biosurfactants represent a modern approach in controlling the proliferation of pathogenic microorganisms and fighting against biofilm formation [5] due to their compatibility with human hosts and to their high stability and specificity [6]. Many yeast species are good biosurfactants producers, Rhodotorula glutinis being able to synthesize carbohydrate-protein complexes [7] or polyol lipids [8] by degrading diesel, alkanes, phenol or industrial wastes [9-11].

The normal alkanes ( $n$-alkanes) are main components of petroleum (crude oil), diesel and natural gas. Nevertheless, some $n$-alkanes, such as $n$-dodecane, can be found in various plant oils with high antimicrobial and antioxidant activities [12] and are used as excipients in drug industry [13]. Moreover, $n$-dodecane is widely used in studies concerning the solid depositions from thermal stressing of jet fuels [14] and as a surrogate for Jet-A fuel in optimizing the operating conditions for catalytic reforming [15]. Therefore, identification of new yeast strains able to assimilate $n$-dodecane and to produce biocompounds with different practical applications, represent an interesting research domain.

Our present work focuses on the ability of the strain Rhotorula glutinis CMGB-RG1 to assimilate $n$-dodecane producing biosurfactants with antimicrobial and antiadhesion abilities. The study integrates in the current direction aimed to develop new ways for combating candidemia.

*email: cs.ortansa@gmail.com 


\section{Materials and methods}

\section{Yeast strains}

The yeast strains Rhotorula glutinis CMGB-RG1, Candida krusei CMGB94 and Candida krusei CMGB-Y8 (Collection of Microorganisms of the Department of Genetics, Faculty of Biology, University of Bucharest, Romania) were maintained in Yeast Peptone Glucose medium with Glycerol (YPG: $5 \mathrm{~g} / \mathrm{L}$ yeast extract, $10 \mathrm{~g} / \mathrm{L}$ peptone, $2 \mathrm{~g} / \mathrm{L}$ glucose with $200 \mathrm{~g} / \mathrm{L}$ glycerol) at $-70^{\circ} \mathrm{C}(\mathrm{Revco}$ LegaciTM Refrigeration System, Copeland, U.K.).

\section{Biodegradation assay}

In order to assess $n$-dodecane biodegradation, the strain $R$. glutinis CMGB-RG1 was grown for 20 hours at $28{ }^{\circ} \mathrm{C}, 150 \mathrm{rpm}$ on YPG medium, and $5 \mathrm{~mL}$ of culture were centrifuged for $6 \mathrm{~min}$ at $6000 \mathrm{rpm}$. The cell pellet was resuspended in water and the inoculum, in a final concentration of $0.3 \times 10^{7}$ cells/mL, was cultivated Yeast Peptone medium (YP: $10 \mathrm{~g} / \mathrm{L}$ yeast extract, $10 \mathrm{~g} / \mathrm{L}$ peptone) supplemented with $1 \% n$-dodecane. The culture was incubated for six days at $28{ }^{\circ} \mathrm{C}$ and $150 \mathrm{rpm}$ in a Certomat BS-T rotary shaker (B. Braun Biotech International, Germany). Samples were collected at time 0 and after two, three and six days. The biodegrading ability of the strain $R$. glutinis CMGB-RG1 was evaluated by monitoring cell counts on Thoma counting chamber [10, 16]. Microscopical observations were also performed at two, three and six days using an optical microscope (Micros, Austria).

\section{Biosurfactant assay}

For obtaining the biosurfactants, $R$. glutinis CMGB-RG1 was grown in YP medium with $1 \% n$ dodecane for $72 \mathrm{~h}$ at $28^{\circ} \mathrm{C}$ and $150 \mathrm{rpm}$.

Biosurfactant production was evaluated using the emulsification index [17]. The cell-free broth (crude biosurfactant) obtained after two, respectively, three days of incubation, was mixed with an equal volume of petroleum and vortexed at $2500 \mathrm{rpm}$ (BioCote vortex, Stuart, U.S.A.). After $24 \mathrm{~h}$ incubation at $22^{\circ} \mathrm{C}$, the emulsification index $\left(\mathrm{E}_{24} \%\right)$ was determined.

\section{Obtaining the concentrated biosurfactant}

The crude biosurfactant $(25 \mathrm{~mL})$ obtained previously was mixed with cold acetone (1:3, v:v), incubated for 20 hours at $4^{\circ} \mathrm{C}$, then centrifuged for $10 \mathrm{~min}$ at $10000 \mathrm{rpm}\left(4^{\circ} \mathrm{C}\right)$. The precipitated biosurfactant was resuspended in $500 \mu \mathrm{L}$ Millipore water for obtaining [50X] concentrated biosurfactant [18].

\section{Antimicrobial activity screening}

For the antimicrobial screening tests, Petri plates with Synthetic Dextrose medium agar (SD: 40 $\mathrm{g} / \mathrm{L}$ glucose, $10 \mathrm{~g} / \mathrm{L}$ peptone, $20 \mathrm{~g} / \mathrm{L}$ agar-agar) were overlaid with $10^{7}$ cells $/ \mathrm{mL}$ from overnight YPG cultures of $C$. krusei CMGB94, respectively, C. krusei CMGB-Y8 from vaginal infections. Equal amounts $(15 \mu \mathrm{L})$ of crude biosurfactant, respectively, [50X] and [25X] concentrated biosurfactant, were spotted on the surface of plates, incubated at $28^{\circ} \mathrm{C}$ and observed for one week.

\section{Antiadhesion activity assay}

Antiadhesion activity of crude and concentrated biosurfactants was tested against $C$. krusei CMGB94 and C. krusei CMGB-Y8 according to [19]. The method estimates the percentage of microbial adhesion reduction reported to a control well. The wells of a sterile 96-well flat-bottomed plastic tissue culture plate were filled with $100 \mu \mathrm{L}$ crude, respectively, [50X] and [25X] concentrated biosurfactant and incubated for $18 \mathrm{~h}$ at $4^{\circ} \mathrm{C}$. After the incubation, the wells were washed twice with Phosphate buffered saline (PBS: $10 \mathrm{Mm} \mathrm{KH}_{2} \mathrm{PO}_{4}, 150 \mathrm{Mm} \mathrm{NaCl}, \mathrm{pH} 7.0$ ). Then, $100 \mu \mathrm{L}$ yeast suspensions from C. krusei CMGB94, respectively, C. krusei CMGB-Y8 $\left(10^{8}\right.$ cells $\left./ \mathrm{mL}\right)$ was added followed by $4 \mathrm{~h}$ incubation at $4^{\circ} \mathrm{C}$. Subsequently, the unattached cells were removed by washing the 
wells with PBS three times. Stabilization of the adherent cells to the well was done using $100 \mu \mathrm{L}$ methanol solution (99\%). After fixation, the wells were emptied and dried at room temperature. In order to count the number of attached microorganisms, we used Crystal violet solution (1\%) added to each well, followed by incubation for $5 \mathrm{~min}$. The plates were then washed under running tap water to remove the excess stain. The adherent microorganisms were solubilized using $100 \mu \mathrm{L}$ of $33 \%$ acetic acid (v/v) and the absorbance was measured at $595 \mathrm{~nm}$. All the samples were done in triplicate and the control wells contained only PBS. The microbial inhibition percentages in presence of crude and, respectively, concentrated biosurfactants were calculated using a formula (1) described by [20] where: Ac is the absorbance of the sample and Ao, the absorbance of the control well.

Microbial inhibition $(\%)=[1-($ Ac/Ao $)] \times 100$ (Formula 1)

The microbial inhibition for the control was set at $0 \%$ to indicate the absence of an antiadhesion compound. The values obtained can be negative showing an increase in microbial adhesion or positive showing antiadhesion properties of the biosurfactant.

\section{Results and discussions}

During previous studies, the strain $R$. glutinis CMGB-RG1 showed the ability to assimilate $n$ alkanes as sole carbon source and to produce biosurfactants [21]. In presence of $n$-dodecane, $R$. glutinis CMGB-RG1 cell population grew rapidly, with a fivefold rate $\left(1.75 \times 10^{7}\right.$ cells $\left./ \mathrm{mL}\right)$ and almost tripled during the next $24 \mathrm{~h}\left(6.05 \times 10^{7}\right.$ cells $\left./ \mathrm{mL}\right)$. The growth continued with a slower rate $\left(14.5 \times 10^{7}\right.$ cells $\left./ \mathrm{mL}\right)$ until the sixth day. The growth of the strain $R$. glutinis CMGB-RG1 on $n$ dodecane followed the same pattern as those described in our studies on other $n$-alkanes [22]. Nevertheless, when compared to previous results, it is obvious that $R$. glutinis CMGB-RG1 adapted best to the presence of $n$-dodecane as sole carbon source with the highest rates of degradation during the first three days of incubation.

The degradation of $n$-dodecane was also assessed using microscopic observations. After two days of incubation, the yeast cells were observed clustered, surrounding scattered hydrocarbon droplets (Figure 1a). Within the next $24 \mathrm{~h}$, the cells multiplied and the degradation of $n$-dodecane became more active, a higher number of droplets of smaller size being noticed (Figure 1b). Finally, by the end of the experiment, the yeast cells appeared more numerous, mingled with hydrocarbon droplets of various sizes (Figure 1c).
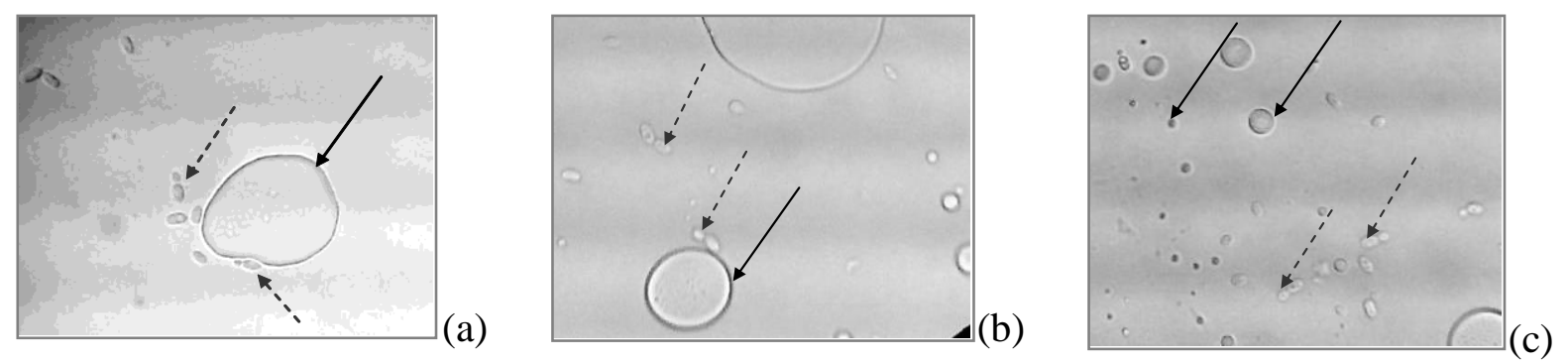

Figure 1. Microscopical appearance of $R$. glutinis CMGB-RG1 cells (dashed lines) interactions with $n$-dodecane (full lines) after (a) two, (b) three and (c) six days of incubation

The production of biosurfactants by $R$. glutinis CMGB-RG1 in presence of $n$-dodecane was evaluated only after two, respectively, three days, during the periods of maximum growth of the cell culture. In both cases, $\mathrm{E}_{24} \%$ had the same value, $29 \%$, indicating that biosurfactant synthesis reached the maximum within the first 48 hours and did not changed afterwards (Figure 2). 


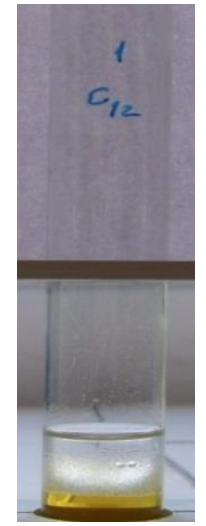

Figure 2. The emulsion formed by $R$. glutinis

CMGB-RG1 crude biosurfactant (cell-free broth) against petroleum

This is interesting, since according to the biodegradation assays, the culture continued to grow within the interval between days two and three (Figure 1). The observation confirms our idea [22] that the $n$-alkanes are incorporated in $R$. glutinis CMGB-RG1 cells both by emulsification, representing, most likely, the predominant mechanism during the first two days, and by passive transport through cell wall channels, which prevails for the next period of incubation.

The antimicrobial tests revealed that the $R$. glutinis CMGB-RG1 biosurfactant was highly active against $C$. krusei CMGB-Y8 when a clear halo was observed surrounding the [50X] biosurfactant spot (Figure 3B.1). The activity decreased with the biosurfactant concentration in the order: [50X] $>[25 \mathrm{X}]$ $>$ crude biosurfactant (Figure 3A.1 and B.1) for both C. krusei strains.

The microscopic observations showed that the $C$. krusei cells suffered a major shock in the presence of [50X] concentrated biosurfactant, presenting large vacuoles (fig. 3A.3 and 3B.3) compared to control cells sampled from the plates outside the area of influence of the biosurfactant (Figure 3A.2 and 3B.2).

A

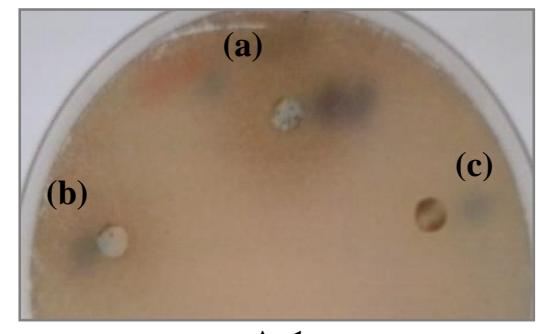

A.1

B

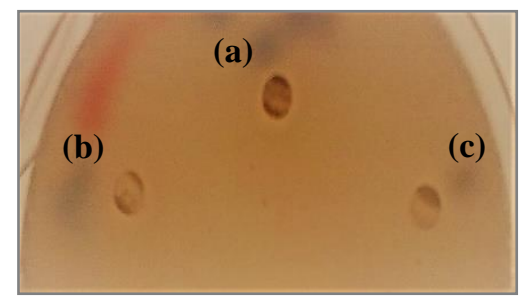

B. 1

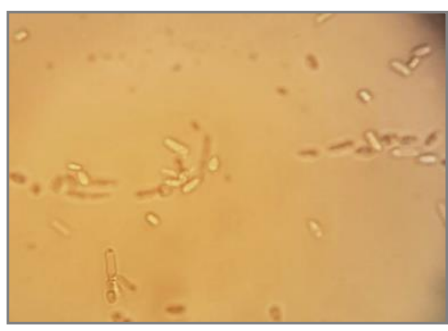

A.2.

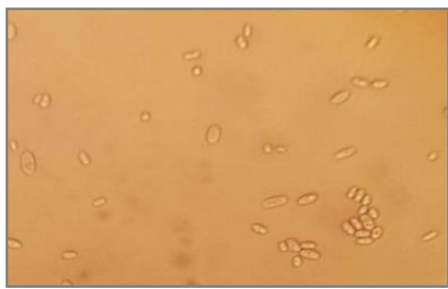

B.2.

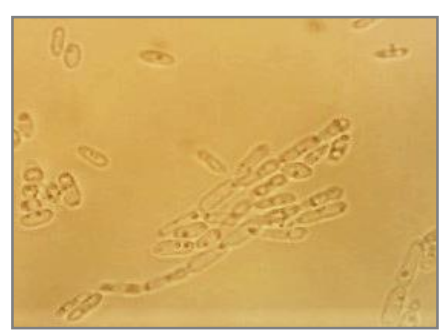

A.3.

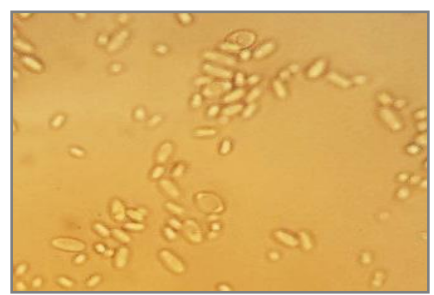

B.3.

Figure 3. Antimicrobial activity of $R$. glutinis CMGB-RG1 bisourfactant against (A) C. krusei CMGB94 and (B) C. krusei CMGB-Y8: A1 and B1 (a) [50X] concentrated, (b) $[25 \mathrm{X}]$ concentrated, (c) crude biosurfactant

The antiadhesion effect of the crude and concentrated biosurfactants was evaluated against the same $C$. krusei strains. The results were calculated as follows: first it was estimated the mean of the values obtain for Ac and Ao and subsequently, the Microbial inhibition (\%) was determined using the formula described in Material and Methods. The biosurfactants showed important antiadhesion activity 
in all cases depending on the concentration of the biosurfactants and the microorganism tested (table $1)$.

Table1. Percentage of growth inhibition obtained after treating the wells with crude, $[25 \mathrm{x}]$ and $[50 \mathrm{x}]$ concentrated biosurfactants

\begin{tabular}{|c|c|c|c|}
\hline \multirow{2}{*}{ Microorganism } & \multicolumn{3}{|c|}{ Biosurfactants } \\
\cline { 2 - 4 } & crude & {$[25 \mathrm{X}]$} & $32.22405 \pm 0.17$ \\
\hline C. krusei CMGB94 & $35.65074 \pm 0.04$ & $26.45799 \pm 0.02$ & $47.50103 \pm 0.21$ \\
\hline C. krusei Y8 & $43.41181 \pm 0.03$ & $41.96613 \pm 0.01$ & [50 \\
\hline
\end{tabular}

Results are expressed as microbial inhibition percentage \pm standard deviation of the values obtained from triplicate experiment.

In the case of $R$. glutinis CMGB-RG1 the antiadhesion activity was higher against the strain $C$. krusei CMGB-Y8 compared to C. krusei CMGB 94 both for the concentrated as well as for the crude biosurfactants (fig. 4), confirming thus the results from the antimicrobial tests.

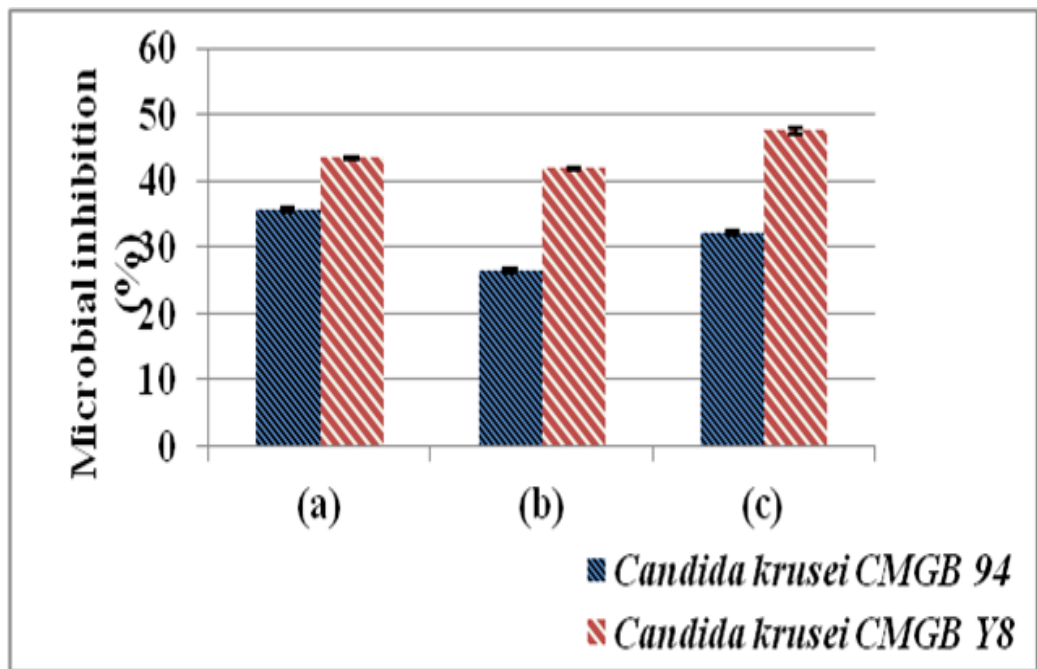

Figure 4. Microbial inhibition (\%) obtained with crude, respectively, concentrated biosurfactants

produced by $R$. glutinis CMGB-RG1. (a) crude; (b) [25X] concentrated; (c) $[50 \mathrm{X}]$ concentrated

Although, we obtained good results in all cases, it seems that adhesion mechanism of $C$. krusei CMGB 94 is best inhibited by the crude biosurfactant (35\%) while in the case of C. krusei CMGB-Y8 best results were obtained when the wells were treated with [50X] concentrated biosurfactant (47\%). Even if the two strains belong to the same species it seems that the source of isolation is an important factor in the adhesion process. C. krusei CMGB 94 is a laboratory collection strain while C. krusei CMGB-Y8 was isolated from vaginal infections and, most probably, developed a more effective mechanism for biofilm formation and adhesion. As a consequence, higher concentrations of biosurfactants are required in order to inhibit the C. krusei CMGB-Y8 biofilm.

Surface adhesion and biofilm formation are strategies developed by pathogenic microorganisms in order to assure their survival in hostile environments like those from the human body [20]. Also, biofilm formation represents a real threat in infection treatment, since the microbial community has different phenotypical properties compared to the individual members (such as drug resistance) [2]. The antiadhesion ability of some chemical compounds is the most effective mean of combating biofilm formation by pathogenic microorganisms. The biosurfactants produced by yeasts might represent interesting antiadhesion agents. Thus, [20] used a biosurfactant produced by a Candida sphaerica strain to inhibit the adhesion of some pathogenic bacterial strains belonging to Lactobacillus, 
Streptococcus and Staphylococcus genera and pathogenic Candida albicans yeast strains. A similar study was conducted by [23] on the antiadhesion ability of a biosurfactant produced by Candida lipolytica. Bacterial biosurfactants can also be used as antiadhesion agents. For example, rhamnolipids produced by Pseudomonas aeruginosa were active against four bacterial and two yeasts strains isolated from explanted voice prostheses [24].

Adhesion to surfaces and cell to cell adhesion are amazing mechanisms developed by the yeast cells. In the process of adhesion a special class of cell-surface proteins called "adhesins" are involved. These proteins bind to specific chemical groups (amino acids or sugar residues) placed on the surface of different cells or surfaces. Until present, a lot of studies aimed to investigate the yeast mechanisms of adhesion. Yeasts adhesion can be divided into two groups according to the chemical groups that interact with the adhesins (sugar residues or peptides). Sometimes, an increase in the cell-surface hydrophobicity can be observed that might promote cells interaction with abiotic surfaces [25]. Therefore, adsorbtion of the biosurfactants on the surface of the abiotic surfaces might interfere with the adhesion mechanism of some yeasts by modifying the hydrophobicity of the surface [23].

\section{Conclusions}

The yeasts belonging to various Candida species are responsible for a large range of candidemia and can also represent serious threats for the use of biomedical devices due to their ability to form biofilms. The yeasts from $R$. glutinis species can produce biosurfactants which can be successfully used for establishing new methods to control the development of infections in medical institutions. The strain $R$. glutinis CMGB-RG1 was able to assimilate $n$-dodecane producing biosurfactants with good emulsifying activity. The synthesized biosurfactants showed antimicrobial and antiahesion properties against pathogenic Candida strains, representing thus an interesting alternative for present medical treatments.

\section{References}

1.MACPHAIL, G.L., TAYLOR, G.D., BUCHANAN-CHELL, M., ROSS, C., WILSON, S., KUREISHI, A., Epidemiology, treatment and outcome of candidemia: a five-year review at three Canadian hospitals, Mycoses, 45, 2002, p. 141.

2.ROSSONI, R.D., BARROS, P.P.D., FREIRE, F., SANTOS, J.D.D., JORGE, A.O.C., JUNQUEIRA, J.C., Study of Microbial Interaction Formed by "Candida krusei" and "Candida glabrata": "In Vitro" and" In Vivo" Studies., Braz. Dent. J., 28, no. 6, 2017, p. 669.

3.BOSINCEANU, D.N., SANDU, I.G., BOSINCEANU, D.G., FORNA, N.C., Study of Candida albicans colonies on a new polymer used to create complete dentures. Rev. Chim. (Bucharest), 65, no. 4, 2014, p. 466.

4.ONIGA, S., ARANICIU, C., PAlAGE, M., STOICA, C., CHIFIRIUC, M.C., MARUTESCU, L., Synthesis and bioevaluation of the antimicrobial features of some new thiazolyl-Azoles in vitro, Rev. Chim. (Bucharest), 67, no. 3, 2016, p. 426.

5.SINGH, P., CAMEOTRA, S.S., Potential applications of microbial surfactants in biomedical sciences, Trends Biotechnol., 22, no. 3, 2004, p. 142.

6.RODRIGUES, L., BANAT, I.M., TEIXEIRA, J., OLIVEIRA, R., Biosurfactants: potential applications in medicine, J. Antimicrob. Chemother., 57, no. 4, 2006, p. 609.

7.NERURKAR, A.S., HINGURAO, K.S., SUTHAR, H.G., Bioemulsifiers from marine microorganisms, J. Sci. Ind. Res., 68, 2009,p. 273.

8.RAHMAN, P.K.S.M., GAKPE, E., Production, characterisation and applications of biosurfactantsReview. Biotechnology, 7, no. 2, 2008, p. 360.

9. OLOKE J.K., GLICK B.R., Production of bioemulsifier by an unusual isolate of salmon/red melanin containing Rhodotorula glutinis, Afr. J. Biotechnol. 4, no. 2, 2005, p. 164. 
10.DE CÁSSIA, M.R., DE SOUZA, C.S., DE BARROS, G.E., BARROS, L.R., LOPES, C., DE FÁTIMA, V., DE QUEIROZ, S.M., Biodegradation of diesel oil by yeasts isolated from the vicinity of Suape Port in the state of Pernambuco - Brazil, Braz. Arch. Biol. Techn. 50, 2007, p. 147.

11.BOŞÇA, A.V., SANIN, S.L.,Temperature and concentration effects on biodegradation kinetics and surface properties of phenol degrading Rhodotorula glutinis, J. Residuals Sci. Tech., 12, no. 3, 2015, p. 183.

12.WUNGSINTAWEEKUL, J., SITTHITHAWORN, W., PUTALUN, W., PFEIFHOFFE, H.W., BRANTNER, A., Antimicrobial, antioxidant activities and chemical composition of selected Thai spices Songklanakarin, J. Sci. Technol., 32, no. 6, 2010, p. 589.

13.GUDIÑA, E.J., RANGARAJAN, V., SEN, R., RODRIGUES, L.R., Potential therapeutic applications of biosurfactants. Trends Pharmacol. Sci., 34, no. 12, 2013, p. 667.

14.LIU, G., HAN, Y., WANG, L., ZHANG, X., MI, Z., Solid deposits from thermal stressing of ndodecane and Chinese RP-3 jet fuel in the presence of several initiators. Energ. Fuel., 23, no. 1, 2009, p. 356.

15.XU, X., ZHANG, S., LI, P., Autothermal reforming of n-dodecane and desulfurized Jet-A fuel for producing hydrogen-rich syngas, Int. J. Hydrog. Energy., 39, no. 34, 2014, p. 19593.

16.PIRÔLlO, M.P.S., MARIANO, A.P., LOVAGLIO, R.B., COSTA, S.G.V.A.O., WALTER, V., HAUSMANN, R., CONTIERO, J., Biosurfactant synthesis by Pseudomonas aeruginosa LBI isolated from a hydrocarbon-contaminated site, J. Appl. Microbiol., 105, 2008, p.1484.

17.COOPER, D.G., GOLDENBERG, B.G., Surface-active agents from two Bacilllus species. Appl. Environ. Microbiol., 53, 1987, p. 224.

18.ILORI, M.O., ADEBUSOYE, S.A., OJO, A.C., Isolation and characterization of hydrocarbondegrading and biosurfactant-producing yeast strains obtained from a polluted lagoon water. World J. Microbiol. Biotechnol., 24, 2008, p. 2539.

19.HEINEMANN, C., VAN HYLCKAMA VLIEG, J.E., JANSSEN, D.B., BUSSCHER, H.J., VAN DER MEI, H.C., REID, G., Purification and characterization of a surface-binding protein from Lactobacillus fermentum RC-14 that inhibits adhesion of Enterococcus faecalis 1131. FEMS Microbiol. Lett., 190, no. 1, 2000, p. 177.

20.LUNA, J.M., RUFINO, R.D., SARUBBO, L.A., RODRIGUES, L.R., TEIXEIRA, J.A., DE CAMPOS-TAKAKI, G.M., Evaluation antimicrobial and antiadhesive properties of the biosurfactant Lunasan produced by Candida sphaerica UCP 0995. Curr. Microbiol., 62, no. 5, 2011, p. 1527.

21.CSUTAK, O., STOICA, I., VASSU, T., Evaluation of production, stability and activity of biosurfactants from yeasts with application in bioremediation of oil-polluted environment, Rev. Chim., 63 (10), 2012, p. 973.

22.CSUTAK, O., VASSU, T., Phylogenetic analysis and characterization of an alkane-degrading yeast strain isolated from oil-polluted soil, Turk. J. Biol., 38, 2014, p. 601.

23.RUFINO, R.D., LUNA, J.M., SARUBBO, L.A., RODRIGUES, L.R.M., TEIXEIRA, J.A.C., CAMPOS-TAKAKI, G.M., Antimicrobial and anti-adhesive potential of a biosurfactant Rufisan produced by Candida lipolytica UCP 0988. Colloids Surf B Biointerfaces, 84, no. 1, 2011, p. 1.

24.RODRIGUES, L.R., BANAT, I.M., MEI, H.C., TEIXEIRA, J.A., OLIVEIRA, R., Interference in adhesion of bacteria and yeasts isolated from explanted voice prostheses to silicone rubber by rhamnolipid biosurfactants. J. Appl. Microbiol., 100, no. 3, 2006, p. 470.

25.VERSTREPEN, K.J., KLIS, F.M., Flocculation, adhesion and biofilm formation in yeasts. Mol. Microbiol, 60, no. 1, 2006, p. 5.

$\overline{\text { Manuscript received: 5.12.2019 }}$ 
